\title{
Serum hyaluronic acid in patients with disseminated neoplasm
}

\author{
G MANLEY, CHRISTINE WARREN \\ From the Department of Chemical Pathology, Torbay Hospital, Torquay, Devon
}

SUMMARY Hyaluronic acid concentrations were measured by a laser nephelometric assay in serum samples from 50 patients with advanced disseminated neoplasm and 50 healthy controls matched for age and sex. The identity of hyaluronic acid was confirmed by a combination of electrophoretic and enzymatic techniques. The mean serum hyaluronic acid concentration for the control group was $1.09 \mathrm{mg} / \mathrm{l}$, with a range of $0-4 \mathrm{mg} / \mathrm{l}$. The mean concentration for patients with neoplastic disease was $10.38 \mathrm{mg} / \mathrm{l}$, with a range of $0-100 \mathrm{mg} / \mathrm{l}$. Sixty two per cent of the patients with disseminated neoplasm had serum hyaluronic acid concentrations above the control range. There was no correlation between the increased concentration of hyaluronic acid and tumour type, serum bilirubin, serum alkaline phosphatase, or serum urea concentrations. There was a higher incidence of hypercalcaemia in patients with increased hyaluronic acid concentrations, but the correlation between hyaluronic acid and calcium concentrations was not significant. In view of the possible role of hyaluronic acid in cellular differentiation and morphogenesis the finding of increased hyaluronic acid concentrations in patients with advanced neoplastic disease may be of fundamental importance in cancer biology.

Hyaluronic acid is a high molecular weight glycosaminoglycan composed of alternate glucosamine and glucuronic acid units. It has a key structural role in connective tissue ground substance ${ }^{1}$ and is also found in unusually high concentrations in fetal tissues. ${ }^{2}$ Since 1957 there have been sporadic reports of hyaluronic acid production by certain tumours. ${ }^{3-5}$ Hyaluronic acid is present in the urine of neonates but is not normally found in the urine of adults. ${ }^{6}$ In 1978 we reported the presence of hyaluronic acid in the urine of about $30 \%$ of patients with disseminated neoplasm. ${ }^{7}$ Having developed a laser nephelometric assay for serum glycosaminoglycans we subsequently found that hyaluronic acid may be detected in low concentration in the serum of some healthy individuals. ${ }^{8}$ We now report the presence of a striking increase in serum hyaluronic acid concentration in some patients with disseminated neoplasm.

\section{Patients and methods}

Fifty patients were studied, all of whom had well documented evidence of advanced neoplastic disease, including hepatic or skeletal metastases, or both. Samples of serum from venous blood were paired

Accepted for publication 22 December 1986 with samples from 50 healthy volunteers matched for age and sex and stored at $-20^{\circ} \mathrm{C}$ for up to four weeks before analysis.

Hyaluronic acid assays were performed by the method of Warren and Manley, ${ }^{8}$ which entails addition of cetylpyridinium chloride to serum and measurement of the cetylpyridinium-chloride-polyanion complexes by laser nephelometry before and after digestion with streptomyces hyaluronidase. For qualitative study of serum glycosaminoglycans serum samples $(5 \mathrm{ml})$ were digested with papain and dialysed against water. Glycosaminoglycans were isolated by precipitation with cetylpyridinium chloride; the complexes were dissociated in $2 \mathrm{M}$ sodium chloride and finally precipitated as sodium salts in ethanol. The isolated glycosaminoglycans were separated by electrophoresis on cellulose acetate membrane in veronal acetate buffer, $\mathrm{pH} 9 \cdot 2$, and calcium acetate buffer, $\mathrm{pH}$ 5.0 , and stained with $1 \%$ alcian blue in $2 \%$ acetic acid. 9 Hyaluronic acid, heparan sulphate, chondroitin sulphate, and streptomyces hyaluronidase were obtained from Miles laboratories. Serum hyaluronic acid was identified by its electrophoretic mobility, which was identical with that of a standard sample of hyaluronic acid at both $\mathrm{pH}$ values, and its total destruction when incubated with streptomyces hyaluronidase ( 15 turbidity reducing units (TRU)/mg glycosaminoglycan) for two hours at $37^{\circ} \mathrm{C}$. 
Serum concentrations of sodium, potassium, chloride, bicarbonate, urea, total protein, albumin, bilirubin, alkaline phosphatase, calcium, and phosphate were measured by continuous flow analysis using a Vickers SP120 RT analyser. Calcium values were corrected to an albumin value of $40 \mathrm{~g} / \mathrm{l}$, assuming $0.025 \mathrm{mmol}$ calcium $\mathrm{g}$ albumin.

\section{Results}

Serum hyaluronic acid concentrations in the control group were in the range $<0.5-4 \mathrm{mg} / \mathrm{l}$, with a mean of $1.09 \mathrm{mg} / \mathrm{l}$; this is in close accord with normal values previously found with this method. ${ }^{8}$ Serum hyaluronic acid concentrations in the patients with neoplastic disease were in the range $<0.5-100 \mathrm{mg} / \mathrm{l}$, with a mean of $10.38 \mathrm{mg} / \mathrm{l}$. Sixty eight per cent of these patients had values above $4 \mathrm{mg} / 1$, and in $48 \%$ this was above $5 \mathrm{mg} / \mathrm{l}$ (fig 1 ).

Because the precise upper limit of normal for serum hyaluronic acid concentration has not yet been established, the patients with neoplastic disease were divided into three groups: group 1 consisted of patients whose serum hyaluronic acid concentration was clearly increased - that is, $>5 \mathrm{mg} / 1$ ( 24 patients); group 2 was an intermediate group with serum hyaluronic acid concentrations of 4-5 mg/l (14 patients);

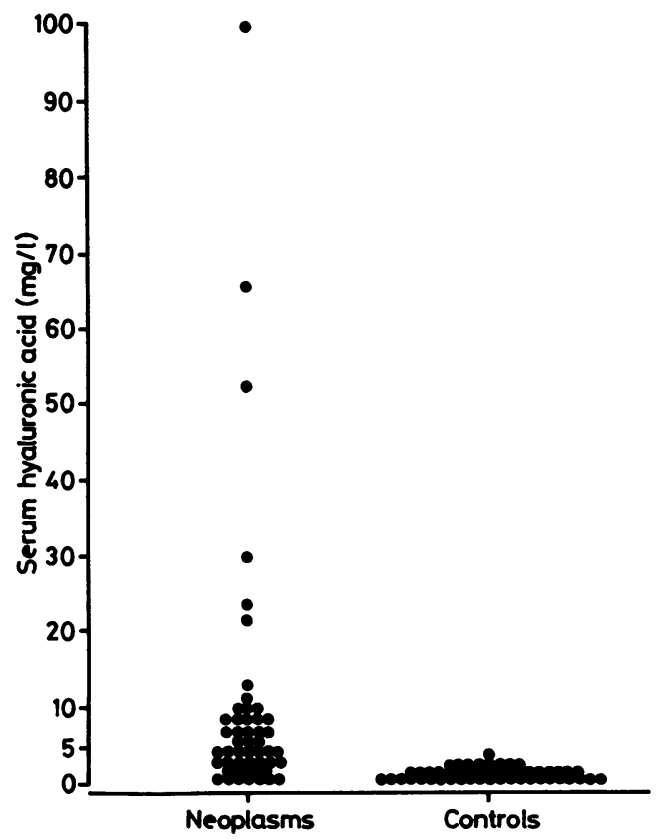

Fig 1 Serum hyaluronic acid concentrations in 50 patients with disseminated neoplasm and in 50 controls matched for age and sex. and group 3 consisted of patients whose serum hyaluronic acid concentration was clearly normal-that is, $<4 \mathrm{mg} / \mathrm{l}$ (12 patients). In group $183 \%$ of patients had increased serum concentrations of alkaline phosphatase, $46 \%$ had increased calcium values, $46 \%$ had increased urea values, and $36 \%$ had increased bilirubin values (table). In group 2 the results were as follows: increased alkaline phosphatase $93 \%$, increased calcium $29 \%$, increased urea $50 \%$, and increased bilirubin $36 \%$. In group 3 the figures were increased alkaline phosphatase $83 \%$, increased calcium $25 \%$, increased urea $33 \%$, and increased bilirubin $33 \%$. There was no clear correlation between serum hyaluronic acid concentrations and tumour type.

Glycosaminoglycans isolated from serum samples with raised hyaluronic acid concentrations by laser nephelometry showed an alcian blue positive electrophoretic band of mobility identical with that of standard hyaluronic acid at $\mathrm{pH} 9 \cdot 2$ (fig 2) and $\mathrm{pH} 5 \cdot 0$. This band was totally destroyed by incubation with streptomyces hyaluronidase, which is highly specific for hyaluronic acid. ${ }^{10}$ This band could not be clearly identified in control samples or in samples from patients with neoplastic disease with normal serum hyaluronic acid concentrations.

\section{Discussion}

The finding of increased, in some cases greatly increased, serum concentrations of hyaluronic acid in more than half of the patients with disseminated neoplasm was unexpected. Clearly, the trace of hyaluronic acid found in the urine of some patients with disseminated neoplasm was but a shadow of the striking phenomenon reported here. ${ }^{7}$

The increased serum concentrations of hyaluronic acid in patients with neoplastic disease are unlikely to be due to hepatic or renal failure. There was no significant difference in serum bilirubin, alkaline phosphatase, or urea concentrations between the patients with increased serum hyaluronic acid concentrations and those with normal values. Slight increases in serum hyaluronic acid concentration have been reported in some patients with inflammatory disease, including rheumatoid arthritis, (up to $7.0 \mathrm{mg} / \mathrm{l}$ ), but the mean value for this group $(1.07 \mathrm{mg} / \mathrm{l})$ was not significantly different from that for the control group. ${ }^{11}$ The incidence of hypercalcaemia in the patients with raised serum hyaluronic acid concentrations (46\%) was higher than that in patients with normal serum hyaluronic acid values $(25 \%)$, but this difference was not significant (p $>0 \cdot 1)$. We have not encountered similar increases in serum hyaluronic acid concentration in cases of nonneoplastic hypercalcaemia. ${ }^{11}$ The series reported here 
Clinical and biochemical data* on 24 patients with disseminated neoplasm and raised serum hyaluronic acid concentrations ( $>5$ mg/l)

\begin{tabular}{|c|c|c|c|c|c|c|c|c|c|}
\hline \multirow{2}{*}{$\begin{array}{l}\text { Case } \\
\text { No }\end{array}$} & \multirow{2}{*}{$\begin{array}{l}\text { Age } \\
\text { (years) }\end{array}$} & \multirow[b]{2}{*}{ Sex } & \multirow[b]{2}{*}{ Tumour type } & \multicolumn{2}{|c|}{$\begin{array}{l}\text { Serum hyaluronic } \\
\text { acid }(m g / l)\end{array}$} & \multirow{2}{*}{$\begin{array}{l}\text { Serum alkaline } \\
\text { phosphatase }(U / l) \\
(20-90 U / l)\end{array}$} & \multirow{2}{*}{$\begin{array}{l}\text { Serum calcium } \\
\text { (corrected })+(\mathrm{mmol} / \mathrm{l}) \\
(2 \cdot 1-2.6 \mathrm{mmol} / \mathrm{l})\end{array}$} & \multirow{2}{*}{$\begin{array}{l}\text { Serum urea } \\
(\mathrm{mmol} / \mathrm{l}) \\
(2.5-6.6 \mathrm{mmol} / \mathrm{l})\end{array}$} & \multirow{2}{*}{ 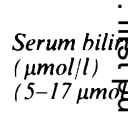 } \\
\hline & & & & Patient & Control & & & & \\
\hline 1 & 77 & $\mathrm{~F}$ & $\begin{array}{l}\text { Adenocarcinoma of } \\
\text { stomach }\end{array}$ & $100 \cdot 0$ & $2 \cdot 2$ & $>500$ & $3 \cdot 23$ & 8.9 & 87 \\
\hline 2 & 73 & $\mathrm{~F}$ & $\begin{array}{l}\text { Squamous carcinoma of } \\
\text { bronchus }\end{array}$ & $7 \cdot 0$ & $1 \cdot 0$ & 182 & $3 \cdot 29$ & $4 \cdot 0$ & 6 \\
\hline 3 & 27 & $\mathbf{F}$ & Adenocarcinoma of ovary & $7 \cdot 0$ & $<0.5$ & 80 & $2 \cdot 31$ & $3 \cdot 5$ & 8 \\
\hline 4 & 76 & $\mathbf{M}$ & Adenocarcinoma of colon & $7 \cdot 0$ & 0.5 & 298 & $2 \cdot 78$ & $23 \cdot 0$ & 11 \\
\hline 5 & 65 & $\mathbf{M}$ & $\begin{array}{l}\text { Adenocarcinoma of } \\
\text { pancreas }\end{array}$ & $7 \cdot 0$ & $<0.5$ & 305 & $2 \cdot 14$ & $2 \cdot 8$ & 7 \\
\hline 6 & 84 & $\mathbf{M}$ & IgG myeloma & $10 \cdot 0$ & $2 \cdot 0$ & 197 & $2 \cdot 42$ & $3 \cdot 7$ & 12 \\
\hline 7 & 58 & $\mathrm{~F}$ & IgG myeloma & $8 \cdot 0$ & 0.75 & 70 & $2 \cdot 39$ & $4 \cdot 2$ & 10 \\
\hline 8 & 66 & $\mathbf{M}$ & IgG myeloma & $10 \cdot 0$ & $<0.5$ & 85 & $2 \cdot 50$ & $9 \cdot 0$ & 8 \\
\hline 9 & 86 & $\mathrm{~F}$ & Adenocarcinoma of colon & $6 \cdot 0$ & 0.5 & 354 & $2 \cdot 41$ & $8 \cdot 2$ & 9 \\
\hline 10 & 74 & $\mathrm{~F}$ & $\begin{array}{l}\text { Squamous carcinoma of } \\
\text { bronchus }\end{array}$ & $13 \cdot 5$ & $1 \cdot 0$ & 132 & $3 \cdot 03$ & $6 \cdot 0$ & 5 \\
\hline 11 & 84 & $\mathbf{F}$ & Adenocarcinoma of breast & $6 \cdot 0$ & $2 \cdot 0$ & 133 & $2 \cdot 32$ & $5 \cdot 0$ & 10 \\
\hline 12 & 64 & M & $\begin{array}{l}\text { Adenocarcinoma of } \\
\text { stomach }\end{array}$ & $30 \cdot 0$ & $<0.5$ & $>500$ & $2 \cdot 72$ & $5 \cdot 0$ & 28 \\
\hline 13 & 40 & $\mathbf{F}$ & Adenocarcinoma of breast & $52 \cdot 5$ & 0.75 & 464 & $2 \cdot 74$ & $8 \cdot 9$ & 72 \\
\hline 14 & 71 & $\mathrm{~F}$ & Adenocarcinoma of breast & $8 \cdot 0$ & $2 \cdot 5$ & 412 & $2 \cdot 25$ & $4 \cdot 0$ & 8 \\
\hline 15 & 67 & $F$ & Adenocarcinoma of ovary & $64 \cdot 5$ & $1 \cdot 0$ & $>500$ & $2 \cdot 75$ & $4 \cdot 5$ & 15 \\
\hline 16 & 61 & $\mathbf{M}$ & $\begin{array}{l}\text { Squamous carcinoma of } \\
\text { bronchus }\end{array}$ & $24 \cdot 0$ & $0 \cdot 5$ & $>500$ & $2 \cdot 85$ & $9 \cdot 9$ & 160 \\
\hline 17 & 53 & F & Adenocarcinoma of ovary & $22 \cdot 0$ & $3 \cdot 0$ & $>500$ & $3 \cdot 81$ & $8 \cdot 5$ & 7 \\
\hline 18 & 55 & $\mathrm{~F}$ & Adenocarcinoma of colon & $10 \cdot 0$ & 0.75 & 126 & $2 \cdot 46$ & $3 \cdot 0$ & 6 \\
\hline 19 & 84 & $\mathrm{~F}$ & Adenocarcinoma of colon & $12 \cdot 5$ & $1 \cdot 0$ & $>500$ & $2 \cdot 44$ & $6 \cdot 3$ & 27 \\
\hline 20 & 67 & $F$ & $\begin{array}{l}\text { Undifferentiated } \\
\text { carcinoma of breast }\end{array}$ & 8.0 & $2 \cdot 2$ & $>500$ & $2 \cdot 12$ & $9 \cdot 7$ & $>300$ \\
\hline 21 & 74 & $F$ & $\begin{array}{l}\text { Squamous carcinoma of } \\
\text { bronchus }\end{array}$ & $8 \cdot 0$ & 0.5 & 73 & $3 \cdot 79$ & $17 \cdot 0$ & 14 \\
\hline 22 & 48 & $\mathbf{F}$ & Adenocarcinoma of breast & $7 \cdot 0$ & $1 \cdot 5$ & $>500$ & $2 \cdot 44$ & $5 \cdot 0$ & 66 \\
\hline 23 & 64 & $\mathbf{M}$ & Adenocarcinoma of colon & 6.0 & $<0.5$ & $>500$ & $2 \cdot 52$ & $5 \cdot 4$ & 53 \\
\hline 24 & 65 & $\mathrm{~F}$ & $\begin{array}{l}\text { Undifferentiated } \\
\text { carcinoma of breast }\end{array}$ & $7 \cdot 0$ & $2 \cdot 5$ & 223 & $3 \cdot 26$ & 5.9 & 5 \\
\hline
\end{tabular}

* Normal ranges are given in parentheses.

tCalcium values were corrected to an albumin of $40 \mathrm{~g} / \mathrm{l}$, assuming $0.025 \mathrm{mmol}$ calcium/g of albumin.

CS

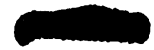

HS

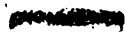

HA

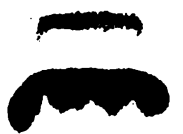

O

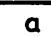

a

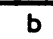

b

C

Fig 2 Electrophoretic patterns of (a) standard glycosaminoglycan mixture containing chondroitin-4-sulphate (CS), heparan sulphate ( $H S)$, and hyaluronic acid $(H A)$; (b) glycosaminoglycans isolated from serum of one patient (case I) with disseminated neoplasm; and (c) glycosaminoglycans isolated from serum of healthy control matched for age and sex. Electrophoretic origin is indicated by 0 . (Veronal acetate buffer, pH 9.2; alcian blue stain.)

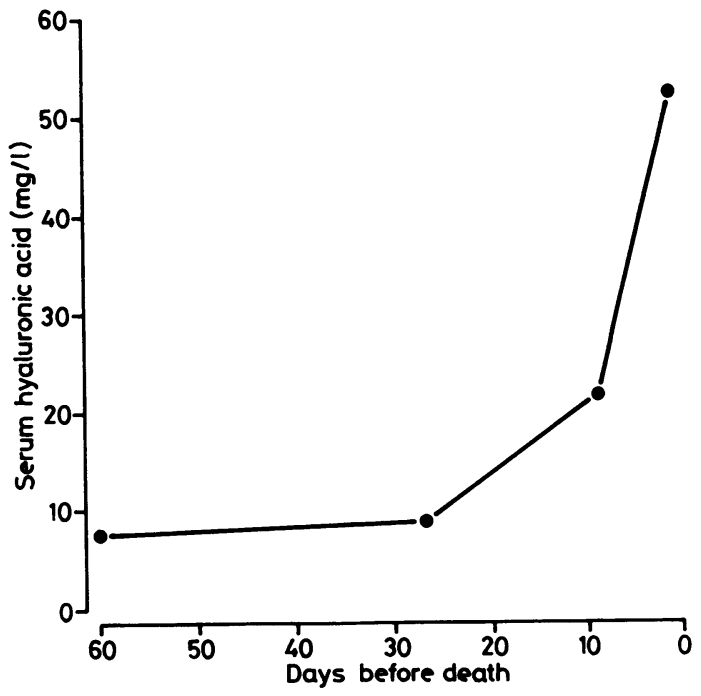

Fig 3 Serial measurements of serum hyaluronic acid concentration in one patient with disseminated carcinoma of breast showing rapid rise towards point of death (case 13). 
is too small to allow firm conclusions to be made about the relation between hypercalcaemia and hyaluronic acidaemia in patients with neoplastic disease, but we suspect that both may be independent phenomena associated with terminal neoplastic disease. In our previous study the patients with hyaluronic acid in their urine were all dead at follow up after three months. ${ }^{7}$ In the present study we were able to assay serial samples in three patients and found rapidly rising serum hyaluronic acid concentrations up to the point of death (fig 3).

Possible reasons for the increased serum concentrations of hyaluronic acid in patients with neoplastic disease include a release of hyaluronic acid from connective tissue ground substance by invading neoplastic cells, the inhibition of hyaluronic acid catabolism by the production of hyaluronidase inhibitors, and the production of hyaluronic acid by the tumour cells themselves or as a result of their interaction with normal cells.

Increased amounts of hyaluronic acid have been shown in some human tumour tissues-notably, neuroblastoma, breast tumours, adenocarcinoma of colon, mesothelioma, and Wilms' tumour. ${ }^{4}$ Increased serum hyaluronic acid concentrations have been reported in patients with neuroblastoma ${ }^{3}$ and in a case of Wilms' tumour. ${ }^{12}$ In neither of these reports was the source of the hyaluronic acid clearly established, but in the case of Wilms' tumour the authors concluded that the production of hyaluronic acid was related to the tumour since concentrations decreased promptly and dramatically on treatment with vincristine and became normal after the tumour was removed. Further evidence that hyaluronic acid may be a product of tumour cells comes from the finding that transformation of green monkey kidney cells with $\mathrm{SV}_{40}$ leads to an accumulation of excess hyaluronic acid as compared with their counterpart normal cells. ${ }^{13}$ On the other hand the work of Knudson et al suggests that the increased production of hyaluronic acid in patients with neoplastic disease may depend on an interaction between tumour cells and normal fibroblasts. ${ }^{14}$ They found that coculture of human LX-1 lung carcinoma cells and normal human fibroblasts produced three times more hyaluronic acid than the sum of that produced by $L X-1$ and fibroblast cultures grown separately.

As hyaluronic acid is found in particularly high concentrations in fetal tissues, ${ }^{2}$ increased serum hyaluronic acid concentrations in patients with neoplastic disease may be an oncofetal phenomenon. It would be a particularly interesting one as hyaluronic acid, as a non-protein is not (in our current concept of genetic information transfer) thought to be a direct gene product.

Of central importance in cellular differentiation, and hence in neoplasia, is the positional sense of a cell in relation to its fellows. Little is understood of mechanisms here, but the intricate patterns of the molecular scaffolding of the intercellular matrix may be important. In connective tissue ground substance hyaluronic acid exists as long intercellular chains of high molecular weight, into which are linked proteoglycans containing variable chains of chondroitin sulphates and keratan sulphates. ${ }^{1}$

In the field of pure speculation, the detailed molecular organisation of the intercellular hyaluronateproteoglycan complexes would seem morphologically suited to a role in intercellular information transfer. In even wilder speculation, might a cell surface defect in the neoplastic cell, which damages its ability to recognise the hyaluronic acid based intercellular scaffolding, lead to an increased production of hyaluronic acid analogous to the increased cellular synthesis of cholesterol in low density lipoprotein receptor defect? ${ }^{15}$ Of course, there is no evidence for this at present, but there is already some evidence that hyaluronic acid has a role in intercellular communication, ${ }^{16}$ cell adhesion, ${ }^{17}$ and morphogenesis. ${ }^{18}$ Against this background the finding of considerably raised serum hyaluronic acid concentrations in patients with a wide range of neoplastic diseases may point to a phenomenon of fundamental importance in neoplasia.

We gratefully acknowledge financial assistance from the Torbay Hospital Special Medical Projects and Research Trust.

\section{References}

1 Muir H. Proteoglycans of cartilage. J Clin Pathol 1978;31 (suppl 12):67-81.

2 Breen M, Johnson RL, Sitlig RA, Weinstein HG, Veis A. The acidic glycosaminoglycans in human foetal development and adult life: cornea, sclera and skin. Connect Tissue Res 1972;1:291-303.

3 Deutsh HF. Some properties of a human serum hyaluronic acid. J Biol Chem 1957;224:767-74.

4 Nigam VN, Brailovsky CA, Bonaventure J. Glycosaminoglycans and proteoglycans in neoplastic tissues and their role in tumour growth and metastasis. In: Varma RS, Varma R, eds. Glycosaminoglycans and proteoglycans in physiological and pathological processes of body systems. Basel: Kager, 1982:354-71.

5 Chiu B, Churg A, Tenglad A, Pearce R, McCaughey WT. Analysis of hyaluronic acid in the diagnosis of malignant mesothelioma. Cancer 1984;54:2195-9.

6 Manley G, Severn M, Hawksworth J. Excretion patterns of glycosaminoglycans and glycoproteins in normal human urine. J Clin Pathol 1968;21:339-45.

7 Manley G, Bower L, Anson A. Urinary excretion of glycosaminoglycans in disseminated neoplasm. J Clin Pathol 1978;31:447-53.

8 Warren C, Manley G. Measurement of serum glycosaminoglycans by laser nephelometry. Clin Chim Acta 1981; 116:369-80. 
9 Manley G. Changes in vascular mucopolysaccharides with age and blood pressure. Br J Exp Pathol 1965;46:125-34.

10 Ohya T, Kaneko Y. Novel hyaluronidase from Streptomyces. Biochim Biophys Acta 1970;198:607-9.

11 Warren C. Human serum glycosaminoglycans in health and disease. Exeter: University of Exeter, 1985:63-9, 190-3. PhD thesis.

12 Wu AHB, Parker OS, Ford L. Hyperviscosity caused by hyaluronic acid in serum in a case of Wilm's tumour. Clin Chem 1984;30:914-6.

13 Makita A, Shimojo H. Polysaccharides of $\mathrm{SV}_{40}$-transformed green monkey kidney cells. Biochim Biophys Acta 1973;304:571-4.

14 Knudson W, Biswas C, Toole BP. Interactions between human tumour cells and fibroblasts stimulates hyaluronate synthesis. Proc Natl Acad Sci USA 1984;81:6767-71.

15 Goldstein JL, Dana SE, Brunschede GY, Brown MS. Genetic heterogeneity in familial hypercholesterolaemia: Evidence for two different mutations affecting functions of low density lipoprotein receptor. Proc Natl Acad Sci USA 1975;2:1092-6.

16 Roblin R, Albert SO, Gelb NA, Black PH. Cell surface changes correlated with density-dependent growth inhibition. Glycosaminoglycan metabolism in 3T3, SV3TV and Con A selected revertant cells. Biochemistry 1975;14:347-57.

17 Pratt RM, Yamada KM, Olden K, Ohanian SH, Hascall VC Tunicamycin-induced alterations in the synthesis of sulphated proteoglycans and cell surface morphology in the chick embryo fibroblast. Exp Cell Res 1979;118:245-52.

18 Toole BP, Jackson G, Gross J. Hyaluronate in morphogenesis Inhibition of chondrogenesis in vitro. Proc Natl Acad Sci USA 1972;69:1384-6.

Requests for reprints to: Dr G Manley, Department of Pathology, Torbay Hospital, Torquay, TQ2 7AA, England. 